\title{
Workflow and decision making of operating room nurses: integrative review
}

\author{
Fluxo de trabalho e tomada de decisão do enfermeiro de centro cirúrgico: revisão integrativa \\ Flujo de trabajo y toma de decisión del enfermero de centro quirúrgico: revisión integradora
}

\author{
Ana Luzia Rodrigues ${ }^{a}$ \\ Fernanda Broering Gomes Torres ${ }^{a}$ \\ Denilsen Carvalho Gomes ${ }^{\mathrm{a}}$ \\ Deborah Ribeiro Carvalho ${ }^{a}$ \\ Eduardo Alves Portela Santos ${ }^{b}$ \\ Marcia Regina Cubas ${ }^{a}$
}

How to cite this article:

Rodrigues AL, Torres FBG, Gomes DC, Carvalho DR, Santos EAP, Cubas MR. Workflow and decision making of operating room nurses: integrative review. Rev Gaúcha Enferm. 2020;41:e20190387. doi: https://doi.org/10.1590/19831447.2020.20190387
Pontifícia Universidade Católica do Paraná (PUCPR), Programa de Pós-Graduação em Tecnologia em Saúde. Curitiba, Paraná, Brasil.

- Pontifícia Universidade Católica do Paraná (PUCPR). Programa de Pós-Graduação em Engenharia de Produção e Sistemas. Curitiba, Paraná, Brasil.

\section{ABSTRACT}

Objective: Identify workflow factors in the operating room and their implications, which influence nurses' decision making. Method: Integrative review of the literature conducted through searches in the databases: Latin American and Caribbean Literature in Health Sciences; Nursing Database; Pubmed; Scopus and Cumulative Index to Nursing and Allied Health Literature. The results were organized into factors related to positive, negative and positive and negative implications.

Results: The sample of 18 articles included examples of factors with positive implications, such as preoperative data collection, negative outcomes, such as lack of human, material and structural resources, and positive and negative outcomes, as preparation for certification.

Conclusions: Factors that influence the decision-making process of nurses are associated to different conditions: client- related conditions and those conditions that go beyond the domain and organization of the surgical environment.

Keywords: Operating room nursing. Workflow. Decision making.

\section{RESUMO}

Objetivo: Identificar fatores do fluxo de trabalho em centro cirúrgico e suas implicações, os quais influenciam a tomada de decisão do enfermeiro.

Método: Revisão integrativa da literatura, realizada por buscas nas bases de dados: Literatura Latino-Americana e do Caribe em Ciências da Saúde; Base de Dados de Enfermagem; Pubmed; Scopus e Cumulative Index to Nursing and Allied Health Literature. Os resultados foram organizados em fatores relacionados a implicações positivas, negativas e positivas e negativas.

Resultados: Pela amostra de 18 artigos, verificaram-se exemplos de fatores com implicações positivas, como coleta de dados no pré-operatório, negativas, como a falta de recursos humanos, materiais e estruturais, e positivas e negativas, como preparação para a certificação.

Conclusões: Fatores que influenciam a tomada de decisão do enfermeiro estão atrelados a distintas condições: as do cliente e as que extrapolam o domínio e a organização do ambiente cirúrgico.

Palavras-chave: Enfermagem de centro cirúrgico. Fluxo de trabalho. Tomada de decisões.

\section{RESUMEN}

Objetivo: Identificar los factores de flujo de trabajo en centro quirúrgico y sus implicaciones, que influyen en la toma de decisiones de las enfermeras.

Método: Revisión integradora de literatura realizada por medio de la consulta en la base de datos: Literatura Latinoamericana y del Caribe en Ciências de la Salud; Base de Datos de Enfermería; Pubmed; Scopus y Cumulative Index to Nursing and Allied Health Literature. Los resultados se organizaron en factores relacionados con implicaciones positivas, negativas y positivas y negativas.

Resultados: La muestra de 18 artículos, hubo ejemplos de factores con implicaciones positivas, como la recopilación de datos preoperatorios, implicaciones negativas, como la falta de recursos humanos, materiales y estructurales, y implicaciones positivas y negativas, como preparación para certificación.

Conclusiones: Los factores que influyen en la toma de decisiones de las enfermeras están vinculados a diferentes condiciones: las del cliente, las que van más allá del dominio y de la organización del entorno quirúrgico.

Palabras clave: Enfermería de quirófano. Flujo de trabajo. Toma de decisiones. 


\section{口INTRODUCTION}

The operating room is a delimited area with restricted access, considered a high-risk environment, dependent on multidisciplinary performance aimed to perform invasive procedures of different complexities ${ }^{(1)}$. Such complexities explain the need for specific physical, material and human resources ${ }^{(2)}$, as well as interaction with the clients and their families at a time of significant physical and emotional impact ${ }^{(3)}$.

In this environment, nursing professionals play a key role to the success and effectiveness of anesthetic-surgical procedures ${ }^{(4)}$. Perioperative nursing care goes beyond the physical space of the operating room, as it occurs in outpatient and inpatient surgical units, hemodynamics and endoscopy services, in order to provide high quality care to surgical clients ${ }^{(4)}$. For this purpose, nurses must coordinate care practice and management activities ${ }^{(5)}$, which requires strategies to overcome difficulties related to the health institution, the staff and the clients ${ }^{(6)}$. It is expected that these professionals have a dynamic profile, technical, scientific and technological knowledge( ${ }^{(4)}$, as well as leadership skills, decision making ability, adaptability, flexibility and teamwork ${ }^{(7)}$.

The practice of operating room nurses involves technical, scientific, social, financial and political factors that interfere in decision-making regarding management and planning of perioperative care ${ }^{(4)}$. There are intrinsic and extrinsic factors in the workflow of these nurses, and the attempt of these professionals to balance the referred factors can cause stress ${ }^{(8)}$ impacting the decision making process ${ }^{(9)}$. Decision-making is the process of making a value judgment to determine what is relevant to the decision, choosing among several alternatives, which usually leads to the definition of the best course of action to achieve the result desired. The workflow, in turn, consists of functions or procedures of the organizational processes ${ }^{(9)}$.

Operating room nurses must recognize the factors involved in their workflow ${ }^{(10)}$ and their implications. This can support the planning and delivery of high quality care(4), making nurses able to make decisions.

The research that led to this article aimed to identify workflow factors in the operating room and their implications, which affect nurses' decision-making processes.

\section{$\square$ METHOD}

This is an integrative literature review, developed in six stages $^{(11)}$. The first stage comprised the identification of the theme and the elaboration of the research question. The theme addressed was decision-making in the workflow of nurses in the operating room, and the guiding questions of the research were, as follows: what workflow factors influence the decision making of operating room nurses? What are the implications of these factors? In this study, the factors are elements that influence the workflow, while the implications consist of the results arising from these factors.

The second stage consisted in the organization of the sample. The bibliographic survey was carried out from January to March 2019 in the following databases: Literatura Latino-Americana e do Caribe em Ciências da Saúde (Lilacs) and Base de Dados de Enfermagem (BDENF), through Biblioteca Virtual em Saúde (BVS), Portal Pubmed, Scopus and Cumulative Index to Nursing and Allied Health Literature (CINAHL).

The descriptors in the list of Health Sciences Descriptors (DeCS) and Medical Subject Headings (MeSH), have been associated with Boolean operators, resulting in the following combinations:"enfermagem de centro cirúrgico" "operating room nursing") AND"fluxo de trabalho" (workflow); "enfermagem de centro cirúrgico" ("operating room nursing") AND "tomada de decisões" ("decision making").

The EndNote software was used for the organization of the corpus. It made it possible to automatically delete duplicate articles in the databases. The following inclusion criteria were adopted: articles published in Portuguese, English and Spanish between 2008 and 2018 that addressed workflow factors that influence decision making of operating room nurses. Editorials and literature reviews were excluded. To minimize selection bias, the studies were independently selected by two researchers. For the full reading of the included articles and those in disagreement, a third researcher was present.

In the third stage, an instrument was filled with the following information: country of origin, year of publication, type of study, level of evidence ${ }^{(12)}$, workflow factors that influenced the decision making of operating room nurses and its implications.

In the fourth stage, an analysis of the selected studies was carried out, which led to the following categories: (i) factors with positive implications - workflow factors that influenced the decision making of operating room nurses and generated useful and constructive results; (ii) factors with negative implications - factors that influenced the decision making of operating room nurses and generated harmful results to the workflow; (iii) factors with positive and negative implications - factors that influenced the decision making of operating room nurses and generated both constructive and harmful results. 
The fifth stage comprised the interpretation and discussion of the results, and the sixth stage, the elaboration of the summary of the available evidence, with the production of the synthesis of the results.

\section{RESULTS}

Database searches identified 263 articles. After the exclusion of duplicate articles, titles and abstracts were read. Of these articles, six did not have open access to the abstract and 135 did not meet the inclusion criteria. Then, 51 full-text articles were selected. Of these, 33 were excluded, and the final sample consisted of 18 articles. The process of selection of publications developed by the three researchers is shown in Figure 1.

The 18 articles analyzed concern descriptive studies, with a quantitative or qualitative approach. Most studies were conducted in Brazil $(n=13)$. Regarding the year of publication, most articles were published in $2015(n=5)$ and $2010(n=3)$. Chart 1 includes information extracted from the publications.

The factors repeatedly identified in the articles were lack of human resources $(4,13,16,19-20,22)$; lack, poor quality or unavailability of equipment ${ }^{(8,13,16,19,23)}$; lack of structural conditions ${ }^{(13,20,22)}$ and nursing time ${ }^{(4,16,24)}$. They were mainly related to the following implications: cancellation of surgeries $(8,13,19-20,22)$; work overload, tiredness and stress ${ }^{(16)}$; reduction of direct care to the client, which is delegated to other members of the nursing staff(4); reduced quality of care ${ }^{(19)}$; decreased functional capacity of the operating room ${ }^{(23)}$ and creation of the equipment technician function ${ }^{(24)}$.

The category "factors with positive implications" included data collected in the preoperative period ${ }^{(14)}$; detection of the client's clinical disorders during the operation ${ }^{(14)}$; use of computational algorithm for surgical programming ${ }^{(15)}$; adoption of a managerial model ${ }^{(17)}$; standardization of processes $^{(5)}$; creation of the equipment technician function ${ }^{(24)}$; adequate time spent in cleaning ${ }^{(25)}$; possibility of relocation of

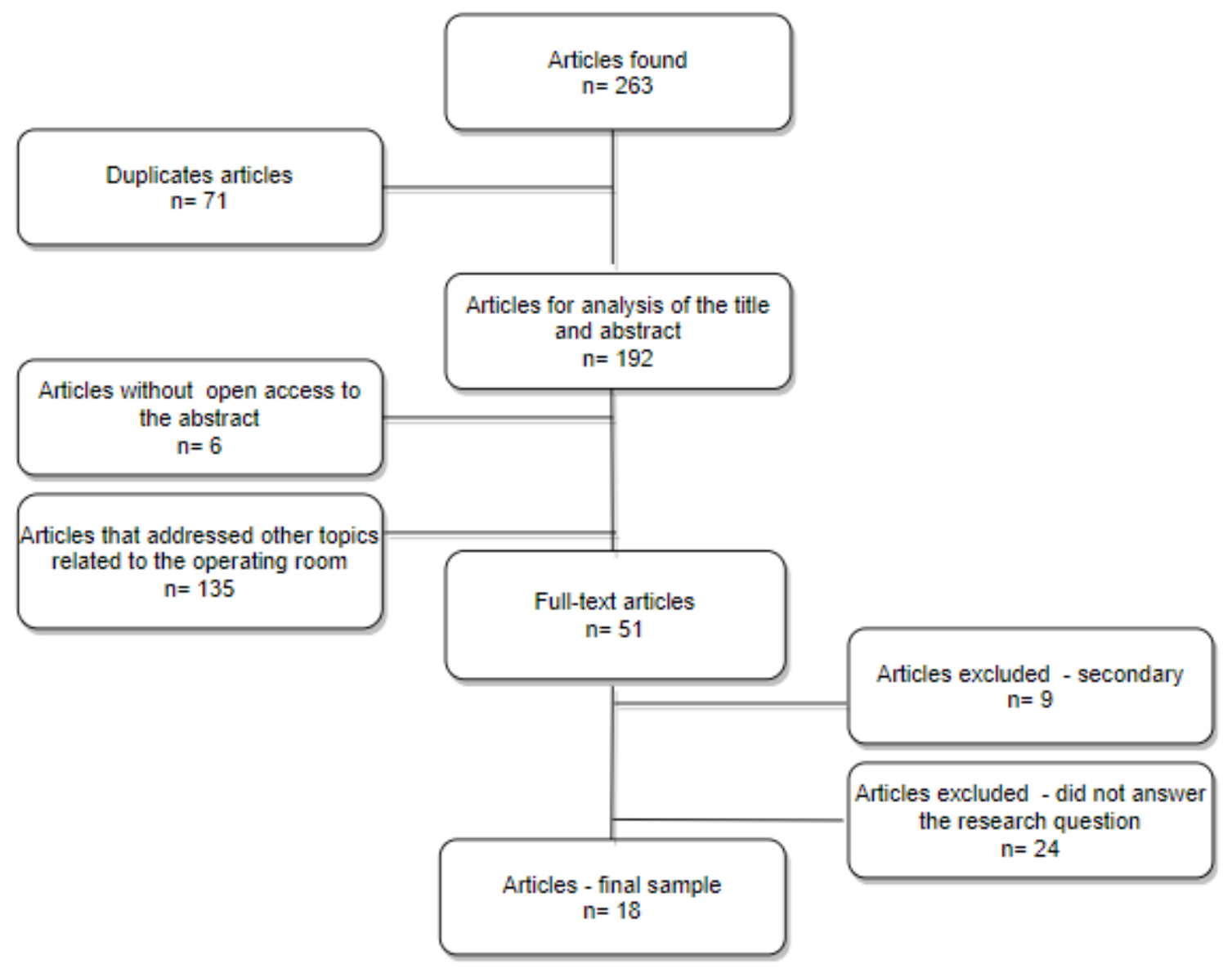

Figure 1 - Sample composition Source: Research data, 2019. 


\begin{tabular}{|c|c|c|c|}
\hline $\begin{array}{l}\text { Country of } \\
\text { origin/year of } \\
\text { publication }\end{array}$ & $\begin{array}{l}\text { Type of study/ } \\
\text { level of evidence }\end{array}$ & Factor & Implications \\
\hline \multirow{5}{*}{$\begin{array}{l}\text { Article }^{(8)} \\
\text { England } 2018\end{array}$} & \multirow{5}{*}{$\begin{array}{l}\text { Descriptive, } \\
\text { qualitative/NI }\end{array}$} & Emergency surgeries & \multirow{5}{*}{$\begin{array}{l}\text { Cancellation of surgeries Late } \\
\text { shift work } \\
\text { Internal groups } \\
\text { examining cancellations }\end{array}$} \\
\hline & & Lack or unavailability of equipment & \\
\hline & & $\begin{array}{l}\text { Client not ready for the ward, or client } \\
\text { cannot return to the ward, or staff not } \\
\text { ready to receive the client in the ward }\end{array}$ & \\
\hline & & $\begin{array}{l}\text { Lack of vacant beds in the immediate } \\
\text { post-anesthetic recovery room }\end{array}$ & \\
\hline & & Delayed surgeries & \\
\hline $\begin{array}{l}\text { Article }{ }^{(10)} \\
\text { USA } 2018\end{array}$ & $\begin{array}{l}\text { Descriptive, } \\
\text { quantitative/VI }\end{array}$ & $\begin{array}{l}\text { Excessive movement of the } \\
\text { circulating nurse }\end{array}$ & $\begin{array}{l}\text { Increased time spent on each } \\
\text { activity of the circulating nurse } \\
\text { due to the distance between } \\
\text { the areas of the operating room, } \\
\text { interrupting the workflow of } \\
\text { surgical procedures }\end{array}$ \\
\hline \multirow[t]{2}{*}{$\begin{array}{l}\text { Article }{ }^{(13)} \\
\text { Brazil } 2016\end{array}$} & \multirow[t]{2}{*}{$\begin{array}{l}\text { Descriptive, } \\
\text { quantitative/NI }\end{array}$} & $\begin{array}{l}\text { Lack of human, material and } \\
\text { structural resources }\end{array}$ & \multirow[t]{2}{*}{ Cancellation of surgeries } \\
\hline & & Client's clinical conditions & \\
\hline \multirow[t]{2}{*}{$\begin{array}{l}\text { Article(14) } \\
\text { Sweden } 2016\end{array}$} & \multirow[t]{2}{*}{$\begin{array}{l}\text { Descriptive, } \\
\text { qualitative/NI }\end{array}$} & $\begin{array}{l}\text { Data collected in the } \\
\text { preoperative period }\end{array}$ & \multirow{2}{*}{$\begin{array}{l}\text { Establishment of communication } \\
\text { with the anesthetist } \\
\text { Meeting the client's fluid } \\
\text { therapy needs }\end{array}$} \\
\hline & & $\begin{array}{l}\text { Detection of the client's clinical } \\
\text { changes during the operation }\end{array}$ & \\
\hline $\begin{array}{l}\text { Article }^{(15)} \\
\text { China } 2015\end{array}$ & $\begin{array}{l}\text { Descriptive, } \\
\text { quantitative/VI }\end{array}$ & $\begin{array}{l}\text { Use of computational algorithm for } \\
\text { surgical programming }\end{array}$ & $\begin{array}{l}\text { Improvement of surgical } \\
\text { programming and allocation of } \\
\text { materials and human resources }\end{array}$ \\
\hline \multirow[t]{4}{*}{$\begin{array}{l}\text { Article }^{(16)} \\
\text { Brazil } 2015\end{array}$} & \multirow[t]{4}{*}{$\begin{array}{l}\text { Descriptive, } \\
\text { qualitative } \mathrm{NI}\end{array}$} & $\begin{array}{l}\text { Lack of adequate time to carry } \\
\text { out activities }\end{array}$ & \multirow[t]{4}{*}{$\begin{array}{l}\text { Work overload, tiredness } \\
\text { and stress }\end{array}$} \\
\hline & & Lack of materials and equipment & \\
\hline & & Lack of planning and organization & \\
\hline & & Lack of human resources & \\
\hline $\begin{array}{l}\text { Article }^{(17)} \\
\text { Brazil } 2015\end{array}$ & $\begin{array}{l}\text { Descriptive, } \\
\text { quantitative/VI }\end{array}$ & Adoption of a management model & $\begin{array}{l}\text { Reduced length of stay in } \\
\text { immediate post-anesthetic } \\
\text { recovery } \\
\text { Reduction in the number of } \\
\text { suspended surgeries Reduced } \\
\text { first surgery delay }\end{array}$ \\
\hline
\end{tabular}

Chart 1 - Country of origin, year of publication, type of study, level of evidence, workflow factors that influenced decision making and its implications 


\begin{tabular}{|c|c|c|c|}
\hline $\begin{array}{l}\text { Country of } \\
\text { origin/year of } \\
\text { publication }\end{array}$ & $\begin{array}{l}\text { Type of study/ } \\
\text { level of evidence }\end{array}$ & Factor & Implications \\
\hline $\begin{array}{l}\text { Article }^{(18)} \\
\text { Brazil } 2015\end{array}$ & $\begin{array}{l}\text { Descriptive, } \\
\text { quantitative/NI }\end{array}$ & $\begin{array}{l}\text { Preparation for certification (acquisition } \\
\text { of equipment, incorporation of security } \\
\text { measures, compliance with bundles, } \\
\text { elaboration of an annual training } \\
\text { program, standardization of practices } \\
\text { and conduct of the nursing team and } \\
\text { adherence to the safe surgery protocol) }\end{array}$ & $\begin{array}{l}\text { Better working conditions } \\
\text { Increased staff stress }\end{array}$ \\
\hline \multirow[t]{4}{*}{$\begin{array}{l}\text { Article }^{(19)} \\
\text { Brazil } 2015\end{array}$} & \multirow[t]{4}{*}{$\begin{array}{l}\text { Descriptive, } \\
\text { quantitative/VI }\end{array}$} & $\begin{array}{l}\text { Lack of human resources and } \\
\text { preoperative evaluation }\end{array}$ & Cancellation of surgeries \\
\hline & & Disorganization of the operating room & \multirow[t]{3}{*}{ Reduced quality of care } \\
\hline & & $\begin{array}{l}\text { Technical failures of the } \\
\text { professionals }\end{array}$ & \\
\hline & & Poor quality devices and equipment & \\
\hline \multirow[t]{3}{*}{$\begin{array}{l}\text { Article }^{(6)} \\
\text { Brazil } 2014\end{array}$} & \multirow[t]{3}{*}{$\begin{array}{l}\text { Descriptive, } \\
\text { qualitative/VI }\end{array}$} & $\begin{array}{l}\text { Failure to communicate } \\
\text { with management }\end{array}$ & \multirow[t]{3}{*}{$\begin{array}{l}\text { Difficulty in the workflow } \\
\text { Reduced quality of care }\end{array}$} \\
\hline & & Lack of provision of resources & \\
\hline & & Excessive non-nursing tasks & \\
\hline $\begin{array}{l}\text { Article }^{(5)} \\
\text { Brazil } 2014\end{array}$ & $\begin{array}{l}\text { Descriptive, } \\
\text { qualitative/VI }\end{array}$ & Standardization of processes & $\begin{array}{l}\text { Lower costs } \\
\text { Easier workflow } \\
\text { Quality improvement }\end{array}$ \\
\hline \multirow{6}{*}{$\begin{array}{l}\text { Article }{ }^{(20)} \\
\text { Brazil } 2013\end{array}$} & \multirow{6}{*}{$\begin{array}{l}\text { Descriptive, } \\
\text { quantitative/VI }\end{array}$} & Absenteeism/client refusal & \multirow[t]{6}{*}{ Cancellation of surgeries } \\
\hline & & Emergency surgeries & \\
\hline & & Client's clinical conditions & \\
\hline & & Failure in the work process & \\
\hline & & Lack of structural conditions & \\
\hline & & Lack of human resources & \\
\hline \multirow[t]{2}{*}{$\begin{array}{l}\text { Article }{ }^{(21)} \\
\text { Brazil } 2013\end{array}$} & \multirow[t]{2}{*}{$\begin{array}{l}\text { Descriptive, } \\
\text { quantitative/VI }\end{array}$} & $\begin{array}{l}\text { Need to warn the medical staff about } \\
\text { risk to } \\
\text { client's safety }\end{array}$ & \multirow[t]{2}{*}{ Retaliation to the nursing team } \\
\hline & & $\begin{array}{l}\text { Low level of autonomy of the nursing } \\
\text { leader in the operating room }\end{array}$ & \\
\hline
\end{tabular}

Chart 1 - Cont. 


\begin{tabular}{|c|c|c|c|}
\hline $\begin{array}{l}\text { Country of } \\
\text { origin/year of } \\
\text { publication }\end{array}$ & $\begin{array}{l}\text { Type of study/ } \\
\text { level of evidence }\end{array}$ & Factor & Implications \\
\hline \multirow{6}{*}{$\begin{array}{l}\text { Article(22) } \\
\text { Brazil } 2010\end{array}$} & \multirow{6}{*}{$\begin{array}{l}\text { Descriptive, } \\
\text { quantitative/VI }\end{array}$} & Absenteeism/client's refusal & \multirow[t]{6}{*}{ Cancellation of surgeries } \\
\hline & & Emergency surgeries & \\
\hline & & Client's clinical conditions & \\
\hline & & Failure in the work process & \\
\hline & & Lack of structural conditions & \\
\hline & & Lack of human resources & \\
\hline \multirow[t]{3}{*}{$\begin{array}{l}\text { Article } \\
\text { Brazil } 2010\end{array}$} & \multirow[t]{3}{*}{$\begin{array}{l}\text { Descriptive, } \\
\text { qualitative/VI }\end{array}$} & Lack of equipment and materials & $\begin{array}{l}\text { Decreased functional capacity of } \\
\text { the operating room }\end{array}$ \\
\hline & & Operating room layout & $\begin{array}{l}\text { Optimization of the workflow } \\
\text { or physical and psychological } \\
\text { exhaustion of the nursing team }\end{array}$ \\
\hline & & Work overload & $\begin{array}{l}\text { Damage to } \\
\text { interpersonal relationships }\end{array}$ \\
\hline \multirow[t]{2}{*}{$\begin{array}{l}\text { Article }{ }^{(24)} \\
\text { USA } 2010\end{array}$} & \multirow[t]{2}{*}{$\begin{array}{l}\text { Descriptive } \\
\text { pilot- project/NI }\end{array}$} & $\begin{array}{l}\text { Creation of the equipment } \\
\text { technician function }\end{array}$ & $\begin{array}{l}\text { Increased time spent in nursing } \\
\text { care for the client and increased } \\
\text { job satisfaction }\end{array}$ \\
\hline & & $\begin{array}{l}\text { Nursing time spent on } \\
\text { non-clinical tasks }\end{array}$ & $\begin{array}{l}\text { Creation of the equipment } \\
\text { technician function }\end{array}$ \\
\hline \multirow[t]{6}{*}{$\begin{array}{l}\text { Article }{ }^{(25)} \\
\text { Brazil } 2009\end{array}$} & \multirow[t]{6}{*}{$\begin{array}{l}\text { Descriptive, } \\
\text { quantitative/NI }\end{array}$} & Delayed surgeries & $\begin{array}{l}\text { Loss of operational capacity } \\
\text { (resistance index) }\end{array}$ \\
\hline & & Cancellation of surgeries & Increased resistance index \\
\hline & & $\begin{array}{l}\text { Possibility of relocation of the } \\
\text { operating room }\end{array}$ & \multirow[t]{2}{*}{$\begin{array}{l}\text { Gain in operational capacity } \\
\text { (optimization index) }\end{array}$} \\
\hline & & Adequate time spent in cleaning & \\
\hline & & High occupancy rate & \multirow{2}{*}{$\begin{array}{l}\text { Excessive use of } \\
\text { operational capacity }\end{array}$} \\
\hline & & $\begin{array}{l}\text { Surgery exceeds the scheduled time, } \\
\text { even when it starts on time }\end{array}$ & \\
\hline \multirow{4}{*}{$\begin{array}{l}\text { Article }^{(4)} \\
\text { Brazil } 2009\end{array}$} & \multirow{4}{*}{$\begin{array}{l}\text { Descriptive, } \\
\text { qualitative } / \mathrm{NI}\end{array}$} & Organizational structure & Difficulty in making decision \\
\hline & & Lack of human resources & \multirow{2}{*}{$\begin{array}{l}\text { Reduction of direct care to } \\
\text { the client, which is delegated } \\
\text { to other members of the } \\
\text { nursing staff }\end{array}$} \\
\hline & & $\begin{array}{l}\text { Nursing time spent on } \\
\text { non-clinical tasks }\end{array}$ & \\
\hline & & $\begin{array}{l}\text { Use of instruments for documentation } \\
\text { of nursing care }\end{array}$ & Guidance on the nursing practice \\
\hline
\end{tabular}

Chart 1 - Cont.

Source: Research data, 2019. 
the operating room ${ }^{(25)}$; and use of instruments to systematize and document nursing practice ${ }^{(4)}$.

The category "factors with negative implications" included: emergency surgery ${ }^{(8,20,22)}$ lack, poor quality or unavailability of equipment $(8,16,19,23)$; problems related to the workflow of inpatient units ${ }^{(8)}$; delay and cancellation of surgeries ${ }^{(8,25) ;}$ excessive movement of the circulating nurse ${ }^{(10)}$; lack of hu$\operatorname{man}^{(4,13,16,19-20,22)}$, material ${ }^{(8,13,16,19-20,23)}$ and structura| ${ }^{(8,13,16,20,22)}$ resources; client's clinical conditions ${ }^{(13,20,22)}$; lack of adequate time to carry out activities ${ }^{(16)}$; lack of planning ${ }^{(6,16,19)}$ and organization ${ }^{(16,19)}$; lack of preoperative evaluation ${ }^{(19)}$; technical failures of professionals ${ }^{(19)}$; poor quality devices and equipment ${ }^{(19)}$; failure to communicate with the management ${ }^{(6)}$; work overload ${ }^{(23)}$, including non-nursing tasks( ${ }^{(6)}$; absenteeism and customer's refusal(20,22); failure in the work process ${ }^{(2,22) \text {; }}$ need to warn the medical staff about risk to client's safety ${ }^{(21)}$; low level of autonomy of the nursing leader ${ }^{(21)}$; high occupancy rate ${ }^{(25)}$; duration of surgical procedure longer than planned $^{(25)}$ and organizational structure ${ }^{(4)}$.

The factors preparation for certification ${ }^{(18)}$; layout of the operating room ${ }^{(23)}$ and nursing time spent on non-clinical tasks ${ }^{(4,24)}$ generated both positive and negative implications. The first factor was related to improvement in working conditions, but also to the increased stress of the staff(18); the second concerned the optimization of the workflow, but also the exhaustion of the nursing team ${ }^{(23)}$ and the third was related to the creation of the equipment technician function and reduction of direct care to the client, which is delegated to other members of the nursing staff.

\section{DISCUSSION}

\section{Factors with positive implications}

The recognition of factors that generate positive implications for the workflow of the operating room can contribute to nurses' decision making. Among these factors is data collection in the preoperative period ${ }^{(14)}$, which allows predicting and more effectively detect the client's clinical changes during the surgical procedure ${ }^{(14)}$. These data support the decision-making process of the teams involved, both of the doctors who (re) manage situations foreseen in the intraoperative period and of nurses who (re) plan the preparation of the environment and the clients and the connection between the necessary support services. In Sweden, the duties of operating room nurses include the management of intraoperative IV fluid administration ${ }^{(14)}$. Thus, the data collected can guide the management of fluid therapy during surgery, which is vital in special situations, e.g. clients with kidney problems.
Pre-operative data collection can be enhanced with the use of instruments to systematize nursing care. This use, which is also associated with positive implications ${ }^{(4)}$, helps to ensure that the real needs of clients and family members are met, establishing care priorities.

Decision making is influenced by the management model adopted in the operating room ${ }^{(17)}$. If the management chooses, for example, to standardize processes, this will reduce costs, facilitate workflow and improve the quality of care ${ }^{(5)}$. A uniform and shared work process favors nurses'autonomy and, consequently, their decision making.

The activities performed by the support staff(25) are also impacted by the standardization of processes and are reflected in the workflow of the nursing team. For example, if an operating room is cleaned within the recommended time, this contributes to an increase in operational capacity ${ }^{(25)}$; otherwise, this will interfere with the workflow, impairing surgical scheduling and requiring prompt decisions of the nurses.

Positive implications are related to increased time spent by the nursing staff in care. The use of a computational algorithm for surgical scheduling ${ }^{(15)}$ supports the nurse in this activity, indicating that the nursing time should be spent in the care of surgical clients. The nurses' time spent on care was maximized by the creation of the equipment technician function ${ }^{(24)}$, since non-specific nursing activities, such as preventive and/or corrective maintenance of equipment, are assigned to another professional.

\section{Factors with negative implications}

The surgical environment poses challenges that arising from its own intrinsic conditions, marked by unpredictability and the constant need for (re) planning and (re) organization ${ }^{(26)}$. The need for emergency surgeries ${ }^{(8,20,22)}$ is one of those challenges that interfere with the workflow in the operating room. In such cases, nurses' decision making involves the room to be used for the procedure and the reorganization of the team, implying relocating, delaying or canceling scheduled surgeries.

The cancellation of surgeries is an implication that does not occur just because of emergency surgeries. The following factors related to this issue were identified: lack of human resources ${ }^{(13,19-20,22),}$ structural ${ }^{(20,22)}$ and materials $s^{(13),}$ the client's clinical conditions ${ }^{(13,20,22)}$, lack of preoperative evaluation ${ }^{(19)}$, absenteeism/client's refusal(20,22) and failure in the work process ${ }^{(20,22)}$.

The client's clinical condition for surgical cancellation $^{(13,20,22)}$ is an unpredictable factor and although it is not directly within the scope of the nurse's decision making, it 
implies that these professionals take managerial decisions to ensure a permanent workflow.

On the other hand, the causes of some delays and cancellations can be avoidable ${ }^{(27)}$, such as absenteeism/client's refusal(20,22) and lack of preoperative evaluation ${ }^{(19)}$. These situations can be avoided with preoperative planning, leading to the optimization of resources ${ }^{(27)}$, which impact the decision making process of operating room nurses.

The challenges posed by the surgical environment are more intense when problems related to lack of materials and equipment ${ }^{(26)}$ and poor quality devices and equipment ${ }^{(19)}$ occur concomitantly. These devices must be available in sufficient quantity and checked in advance. For proper functioning, preventive and periodic maintenance is essential(2). However, it is argued that the time spent on these activities could be devoted to client care ${ }^{(24)}$.

The findings report activities that keep nurses away from the client, such as installing and moving equipment (24), which generate excessive non-nursing tasks, reducing the amount of nursing care to clients in the surgical context. Proper management ensures these tasks are delegated to non-professional support staff(24), prioritizing nursing care and minimizing the overload of activities. As for overload related to the excessive use of operational capacity, it is due to the high occupancy rate and to the fact that surgeries often take longer than planned ${ }^{(25)}$. This situation can reduce customer safety and stress the professionals.

The workflow of the surgical environment is also affected by deficiencies in physical structure, such as the lack of ICU vacant beds ${ }^{(25)}$. If this unavailability of beds is prior to the procedure, it may result in the nurse's decision to cancel the surgery; if unavailability occurs after the surgical procedure, it can result in the occupation of beds used for immediate post-anesthetic recovery.

The challenges imposed by the physical environment can affect the safety of clients and the health staff. The higher the number of tasks performed by nurses in different hospital wards, the greater the chance that the workflow ${ }^{(10)}$ will be interrupted due to the waiting time for materials and equipment.

In the development of physical structure projects for these units, the functions of the different team members, the types of activities performed by them, as well as their interaction with the physical environment and the equipment of the operating room should be considered ${ }^{(10)}$. The importance of the nurse's managerial decision-making regarding the provision of operating rooms and support rooms is highlighted here. This professional must understand how the physical environment can interfere with workflow and care, in order to provide well-being, comfort and safety to clients and professionals.

The sizing and qualification of the work team are also relevant factors in the surgical context ${ }^{(2)}$. Incorrect sizing of the nursing team leads to a reorganization of activities, causing work overload to the professionals and jeopardizing clients' safety. The findings brought factors from the inpatient units ${ }^{(8)}$ that may be related to the lack of professionals to refer clients to other services or to receive them. These situations interfere with the flow of the surgical center, and nurses are responsible for making decisions to reorganize the work.

A study conducted in Chinese hospitals found that proper sizing of the nursing team and organizational support are directly related to the improvement of client safety ${ }^{(28)}$. The implications identified by this study point out that incorrect sizing and lack of time, planning and organization generate work overload, tiredness and stress for the professionals ${ }^{(16),}$ and can even cause damage to interpersonal relationships ${ }^{(23)}$. In this regard, to ensure the proper sizing of the nursing staff, the decisions made by operating room nurses and by the management should be based on indicators that justify the referred sizing.

The factor technical failure of professionals ${ }^{(19)}$ brings to light the debate about qualification issues. Training and the implementation of protocols contribute to the standardization of nursing practices ${ }^{(18)}$, minimizing technical failures ${ }^{(19)}$ and costs and contributing to the workflow and improvement of care ${ }^{(5)}$.

Nurses need constant updating to improve clinical reasoning, which is essential for the application of the nursing process ${ }^{(29)}$. The implications demonstrate that guidance on professional practice, ensuring continuous care, can be facilitated by the use of instruments that document the nursing process in the surgical environment ${ }^{(4)}$. This can support the decision-making process of operating room nurses when they establish care priorities.

The findings also reveal that the lack of autonomy of operating room nurses is a factor that interferes with decision making. Because of this lack of autonomy, nursing professionals may fail to take the necessary measures to face situations that put the clients at risk, because they fear retaliation ${ }^{(10)}$. On the other hand, experienced nurses can use intuition in their decision-making process ${ }^{(30)}$, making it more autonomous.

The lack of autonomy of nurses can be partly explained by their lack of experience in certain situations. However, autonomy issues go beyond the individual experience of each professional, including factors related to 
politics, the organization's view, management model and organizational structure.

Data collected, such as test results and breaking of the fast ${ }^{(20)}$, included in the surgical checklist ${ }^{(8)}$, are factors that can support nurses' decisions on the need to comply with the requirements for starting the surgical procedure, which implies guidance on conducts in the surgical environment.

In this regard, communication between the surgeon, the anesthesiologist and the nursing team is important ${ }^{(27)}$. As for communication failures in other areas, (such as management, for example) they make it difficult to carry out work

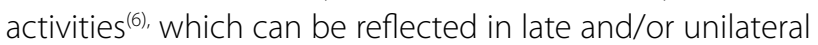
decisions that can be harmful in a dynamic context like the operating room.

\section{Factors with positive and negative implications}

Activities related to the preparation for certification can generate stress in the work staff(18), due to the necessary adjustments to achieve improvements. However, the implemented processes can facilitate nurses' decision-making process.

The layout of the operating room can also facilitate the nurses' decision making. For example, the nursing station, when located at the center of the unit, allows nurses to have a broad view of what occurs in the preoperative reception and post-anesthetic recovery ${ }^{(23)}$. On the other hand, when hospital facilities layouts are not properly designed, this can have a negative impact on the workflow ${ }^{(23)}$. These issues lead to the discussion about decisions on the adaptation of the physical structure and a more appropriate layout of support rooms, to facilitate the workflow and reduce the exhaustion of health professionals.

Although the time spent by nurses on administrative tasks ${ }^{(24)}$ is a negative factor, it influenced the creation of the equipment technician function ${ }^{(24)}$, reducing the number of tasks that keep nurses away from care duties ${ }^{(4)}$. When they are more actively involved in care duties, nurses can make decisions that better meet the needs of surgical clients.

\section{CONCLUSIONS}

Data collected in the preoperative period; detection of client's clinical changes during the operation; the use of a computational algorithm for surgical programming; adoption of a managerial model; standardization of processes; creation of the equipment technician function; adequate time spent in cleaning; possibility of relocating the operating room and use of instruments to systematize and document nursing practice were identified as factors that influence the decision making of the operating room nurse and had positive implications.

On the other hand, emergency surgeries; lack, poor quality or unavailability of equipment; problems related to the workflow of inpatient units; delay and cancellation of surgeries; excessive movement of circulating nurses; lack of human, material and structural resources; client's clinical conditions; lack of adequate time to carry out the activities; lack of planning and organization; lack of preoperative evaluation; technical failures of professionals; poor quality devices; failure to communicate with management; work overload, including non-nursing activities; absenteeism and client's refusal; failure in the work process; need to warn the medical staff about risk to client's safety; lack of autonomy of the nursing leader; high occupancy rate; duration of surgeries longer than previously planned and organizational structure were identified as workflow factors that influence the decision making of the operating room nurse and had negative implications.

Preparation for certification; layout of the operating room and nursing time spent on non-clinical tasks were factors with positive and negative implications.

Factors that influence the decision making of nurses can be associated to different conditions: client-related conditions and those conditions that go beyond the domain and organization of the surgical environment.

The present study supports the performance of nurses in the operating room, with the purpose of maximizing actions to obtain positive implications and carrying out preventive actions aimed at minimizing the negative implications. If nurses are aware that the time spent on cleaning impacts the workflow, their decisions will take into account this stage of the operating room routine, avoiding the need for rescheduling or delays. Nurses may also encourage inter-sector interaction, in order to improve the collection and sharing of data from the preoperative period that interfere with the perioperative period.

The contributions of this study are also related to the scope of nursing education, especially knowledge of the resources and activities inherent to the surgical environment. The analysis of factors and their implications can contribute to the teaching of nursing planning.

The factors associated to the positive, negative or both implications directly influence the management of care provided to the clients and not merely the administrative management of the surgical environment.

One limitation of this study is the small number of international articles included in the review and the few available studies with a high level of evidence, which can compromise the representativeness of the sample and generalization and 
use of the results. However, the study provided a synthesis of important issues in the workflow of operating room nurses.

\section{DEFERENCES}

1. Carvalho PA, Göttems LBD, Pires MRGM, Oliveira MLCD. Safety culture in the operating room of a public hospital in the perception of healthcare professionals. Rev Latino-Am Enfermagem. 2015;23(6):1041-8. doi: https:// doi.org/10.1590/0104- 1169.0669.2647

2. Gutierres LS, Santos JLG, Peiter CC, Menegon FHA, Sebold LF, Erdmann AL. Good practices for patient safety in the operating room: nurses' recommendations. Rev Bras Enferm. 2018;71(6):2775-82. doi: https://doi. org/10.1590/0034-7167-2018-0449

3. Bilik 0, Karayurt 0, Savci A, Damar HT. Experiences of adolescents and their families in the short-term after scoliosis surgery. Acta Paul Enferm. 2018;31(4):342-50. doi: https://doi.org/10.1590/1982-0194201800049

4. Grittem L, Meier MJ, Peres AM. Sistematization of perioperative care a qualitative research. Online Braz J Nurs. 2009;8(3) doi: https://doi. org/10.5935/1676-4285.20092588

5. Richa AC, Guimarães SM, Cardoso TV. Gestão por padronização de processos: a percepção dos enfermeiros de centro cirúrgico. Rev SOBECC. 2014;19(1):3-10. doi: https://doi.org/10.4322/sobecc.2014.003

6. Santos FK, Silva MVG, Gomes AMT. Understanding the forms of care of nurses in the operating room - a construction based on the grounded theory method. Texto Contexto - Enferm. 2014;23(3):696-703. doi: https://doi. org/10.1590/0104-07072014001140013

7. DalcólC,GaranhaniML.Managementroleofsurgical centernurses: perceptions by means ofimages. RevEletrEnferm.2016;18:e1168.doi:https://doi.org/10.5216/ ree.v18.34888

8. McGarry JR, Pope C, Green SM. Perioperative nursing: maintaining momentum and staying safe. J Res Nurs. 2018;23(8):727-39. doi: https://doi. org/10.1177/17449887118808835

9. Descritores em Ciências da Saúde: DeCS [Internet]. ed. 2017. São Paulo (SP): BIREME / OPAS / OMS. 2017 [updated 2019 Jun; cited 2019 0ct 13]. Available from: http://decs.bvs.br/

10. Bayramzadeh S, Joseph A, San D, Khoshkenar A, Taaffe K, Jafarifiroozabadi R, et al. The impact of operating room layout on circulating nurse's work patterns and flow disruptions: a behavioral mapping study. Herd. 2018;11(3):124-38. doi: https://doi.org/10.1177/1937586717751124

11. Mendes KDS, Silveira RCCP, Galvão CM. Revisão integrativa: método de pesquisa para a incorporação de evidências na saúde e na enfermagem. Texto Contexto Enferm. 2008;17(4):758-64. doi: https://doi.org/10.1590/ S0104-07072008000400018

12. Melnyk, BM, Fineout-Overholt, E. Making the case for evidence-based practice. In: Melnyk BM, Fineout-Overholt E. Evidence based practice in nursing \& healthcare: a guide to best practice. Philadelphia: LippincottWilliams \& Wilkins; 2005. p. 3-24.

13. Sampaio CEP, Gonçalves RA, Seabra Júnior HC. Determination of surgery suspension factors and their constributions with nursing assistance. Rev Pesq Cuid Fundam. 2016;8(3):4813-20. doi: https://doi.org/10.9789/21755361.2016.v8i3.4813-4820

14. Calebrant H, Sandh M, Jansson I. How the nurse anesthetist decides to manage perioperative fluid status. J Perianesth Nurs. 2016;31(5):406-14. doi: https:// doi.org/10.1016/j.jopan.2015.04.005
15. Xiang W, Yin J, Lim G. A short-term operating room surgery scheduling problem integrating multiple nurses roster constraints. Artif Intell Med. 2015;63(2):91-106. doi: https://doi.org/10.1016/j.artmed.2014.12.005

16. Jacques JPB, Ribeiro RP, Martins JT, Rizzi DS, Schimidt DRC. Geradores de estresse para os trabalhadores de enfermagem de centro cirúrgico. Semina Cienc Biol Saúde. 2015;36(1Supl):25-32. doi: https://doi. org/10.5433/1679-0367.2015v36n1Suplp25

17. Gaspar AF, Martone D, Carraro DC, Ferreira GSA, Ferreira Filho JA, Cardoso $R$, et al. Impacto da implantação de um novo modelo de gestão embasado em indicadores no bloco cirúrgico de um hospital universitário terciário. Medicina (Ribeirão Preto). 2015;48(1):33-40. doi: https://doi.org/10.11606/ issn.2176-7262.v48i1p33-40

18. Fernandes HMLG, Peniche ACG. Perception of the nursing team of a surgical center regarding hospital accreditation at a university hospital. Rev Esc Enferm USP. 2015;49(esp):22-8. doi: https://doi.org/10.1590/ S0080-623420150000700004

19. Bezerra WR, Bezerra ALQ, Paranaguai TTB, Bernardes MJC, Teixeira CC. Occurrence of incidents at a surgical center: a documentary study. Rev Eletr Enferm 2015;17(4). doi: https://doi.org/10.5216/ree.v17i4.33339

20. Macedo JM, Kano JÁ, Braga EM, Garcia MA, Caldeira SM. Cancelamento de cirurgias em um hospital universitário: causas e tempo de espera para novo procedimento. Rev SOBECC. 2013 [cited 2019 Mar 2];18(1):26-34. Available from: http://hdl.handle.net/11449/140728

21. Bohomol E, Tartali JA. Adverse effects in surgical patients: knowledge of the nursing professionals. Acta Paul Enferm. 2013;26(4):376-81. doi: https:// doi.org/10.1590/S0103- 21002013000400012

22. Souza NVDO, Mauricio VC, Marques LG, Mello CV, Leite GFP. Determinantes para suspensões cirúrgicas em um hospital universitário. Rev Min Enferm. 2010 [cited 2019 Feb 24];14(1):82-7. Available from: http://www.reme.org. $\mathrm{br} /$ artigo/detalhes/91

23. Silva DC, Alvim NAT. Ambiente do centro cirúrgico e os elementos que 0 integram: implicações para os cuidados de enfermagem. Rev Bras Enferm. 2010;63(3):427-34. doi: https://doi.org/10.1590/S0034-71672010000300 013

24. Hemingway M, Freehan M, Morrissey L. Expanding the role of nonclinical personnel in the OR. AORN J. 2010;91(6):753-61. doi: https://doi. org/10.1016/j.aorn.2009.11.067

25. Nepote MHA, Monteiro IU, Hardy E. Association between operational indexes and the utilization rate of a general surgery center. Rev Latino-Am Enfermagem. 2009;17(4):529-34. doi:https://doi.org/10.1590/S0104-1169 2009000400015

26. Martins FZ, Dall'Agnol CM. Surgical center: challenges and strategies for nurses in managerial activities. Rev Gaúcha Enferm. 2016;37(4):e56945. doi: https://doi.org/10.1590/1983-1447.2016.04.56945

27. Naik SV, Dhulkhed VK, Shinde RH. A prospective study on operation theater utilization time and most common causes of delays and cancellations of scheduled surgeries in a 1000-bedded tertiary care rural hospital with a view to optimize the utilization of operation theater. Anesth Essays Res. 2018 [cited 2019 Feb 24];12(4):797-802. Available from: https://www.ncbi.nlm. nih.gov/pmc/articles/PMC6319069/

28. Liu X, Zheng J, Liu K, J Baggs, Liu J, Wu Y, et al. Hospital nursing organizational factors, nursing care left undone, and nurse burnout as predictors of patient safety: a structural equation modeling analysis. Int J Nurs Stud. 2018;86:829. doi: https://doi.org/10.1016/j.ijnurstu.2018.05.005 
29. Riegel F, Oliveira Jr NJ. Nursing process: implications for the safety of surgical patients. Cogitare Enferm. 2017;22(1):1-5. doi: https://doi.org/10.5380/ ce.v22i1.45577

30. Nibbelink CW, Brewer BB. Decision-making in nursing practice: an integrative literature review. J Clin Nurs. 2018;27:917-28. doi: https://doi.org/10.1111/ jocn. 14151

\section{Acknowledgments:}

This study was carried out with the support of the Coordination for the Improvement of Higher Education Personnel - Brazil (CAPES) - Financing Code 001.

\section{- Corresponding author:}

Ana Luzia Rodrigues

E-mail:analuzia64@hotmail.com

\section{Associate editor:}

\section{Editor-in-chief:}

